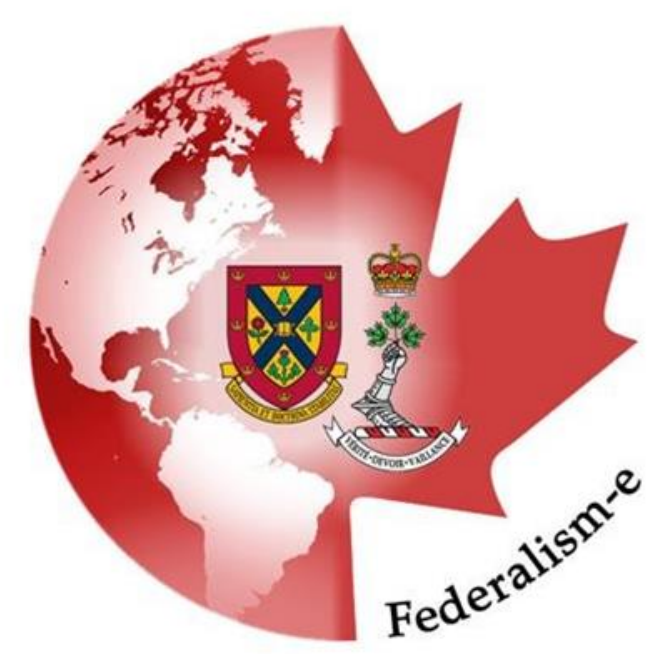

\title{
The Viability of Secession: The Case of Quebec
}

Timothy Phelan, Queen's University

Quebec nationalism is one of the defining forces of Canadian politics in the twentieth century. Indeed, it has been embraced by some leaders and reviled by others. Certainly, it has produced great tension in a country which constitutionally enshrines the values of "peace, order, and good government." (The Constitution Act, 1867, UK) Additionally, secession has become an increasingly important tool for the resolution of ethnic conflict. Donald Horowitz defines secession as "an attempt by an ethnic group claiming a homeland to withdraw with its territory from the authority of a larger state." (Horowitz D. L., 2013, p. 158) For example, in the past twenty five years, Quebec has held two referenda on the subject and threatened several others, Scotland held one in 2014, and Spain deemed a secession referendum in Catalonia, to be illegal. (BBC News Scotland, September 19, 2014 and National Geographic, October 11, 2014) In this way, all three ethnic groups (i.e., Quebecers, Scots, and Catalans) are seeking to gain political, cultural, and ethnic autonomy from their respective rump states by forming their own states.

This paper is focused on the case of secession in Quebec. Particularly, it seeks to answer three questions: (1) Does Quebec have the legal right to secede? (2) If so, what are 
some of the policy implications that would arise if Quebec were to secede? And (3) is secession a viable option for Quebec and Canada? As such, the paper is divided into four parts. The first section outlines some of the existing scholarship on secession in an attempt to demonstrate the lack of attention to the practical implications of secession. The next section analyses the Supreme Court of Canada's secession reference, and The Clarity Act (2000) in a discussion on the legal right of Quebec to secede from the Canadian Federation. The paper then moves into an analysis of the logistical and other considerations that must be addressed should Quebec decide to secede. Particularly, I will discuss Quebec's future in international agreements and organizations, considerations to be made for Aboriginal Peoples living in Quebec, territorial boundaries, and the future of Quebec's economy. The final part of this paper discusses the viability of secession for Quebec and reflects on its implications for other nations considering secession.

\section{Literature Review: The State of the Debate on Secession}

Much of the literature on the subject of secession is focussed on the theoretical conditions conducive to secession and outlining the ethical considerations to be made when assessing the viability of secession. However, the existing scholarship falls severely short in demonstrating the practical policy implications (i.e., political, financial, economic, social, and territorial) that accompany it. This paper will argue that, while secession is possible, the policy negotiations that must occur in order to facilitate secession make it difficult to execute successfully and expediently. With the broad range of other difference management tools at the government's disposal, secession should be viewed as a last resort.

Margaret Moore outlines the various ethical arguments for and against secession in an attempt to understand the secessionist debate. She outlines three major theoretical stances: statist, just cause, and choice. First, the statist theory fundamentally opposes the right to secession on the normative grounds that the state system is facilitative of peace and stability; secession would threaten this, thus making it an illegitimate form of political action. Alternatively, just cause theories suggest that secession can be legitimate when the ethnic group has been subjected to various injustices by the state. However, as Moore explains, there are many ambiguities surrounding exactly what constitutes an "injustice" and "the state" (i.e., the people or the system). Lastly, choice theorists argue that legitimate 
secession is not predicated on a cause of some sort, but simply on the citizens' democratic expression of a desire to secede. (Moore, M., 2010, p. 76 to 83) In short, in focussing on the legitimacy of secession and the normative arguments for doing so, Moore has neglected the practical policy implications of allowing a given territory to secede.

Christopher Wellman directly confronts the various theoretical stances on the morality of secession to develop another, hybrid, theoretical framework in assessing its legitimacy. For Wellman, statists are correct in asserting the importance of state sovereignty and territorial control in maintaining peace and stability. Wellman also acknowledges the value of political self-determination, touted by nationalists as necessary for peace and stability. (Wellman, C., 2010, p. 21) However, he argues that just secession depends, not on the cultural characteristics of the seceding group, but on their ability to govern after they leave the federation. He writes:

[My view] diverges from statism in denying that legitimate states have an absolute right to retain their territorial boundaries as long as they do not treat their constituents unjustly, and it differs from the nationalist view by singling out a separatist group's political capacity (rather than its cultural characteristics) as the key feature that would accord it a primary right to secede. (Wellman, C., 2010, p. 23)

In this way, Wellman proposes a hybrid justification for secession that acknowledges the value of self-determination, but maintains the importance of stability. By doing so, Wellman comes closest to acknowledging the policy implications of secession, but still fails to fully develop this idea.

The case of Quebec provides a useful framework to address the shortfalls of the existing academic scholarship. The next sections outline the labyrinth of negotiations that must be navigated through in order to successfully execute Quebec's secession. From the ambiguity in the Secession Reference, to the policy implications that would arise, the negotiations that must occur in order to facilitate secession make it an inefficient and undesirable tool for conflict resolution. Moreover, due to the plethora of alternative options, secession should be viewed as a last resort. 


\section{On The Right to Secede: The Supreme Court Reference}

On August 20, 1998, the Supreme Court released the Quebec Secession Reference; this was their response to three questions raised by the federal government relating to Quebec's right to declare secession unilaterally. For the justices, the right to unilateral secession was the right to secede without negotiating with the other provinces and the federal government. Ultimately, the Supreme Court ruled that the secession of Quebec would require a constitutional amendment and, therefore, could not be undertaken without negotiation. However, they also ruled that this negotiation could be initiated by Quebec if a "clear majority" of Quebecers, after being asked a "clear question," voted in favour of secession. This would confer upon the governments of Canada and the provinces an obligation to enter into good-faith negotiations with Quebec on the terms of secession. They also noted that secession should not be entered into lightly due to the logistical implications that it would confer on both the government and its citizens. (Supreme Court of Canada, 2010, p. 261) Lastly, the Supreme Court stated that "[w]hile negotiations would have to contemplate the possibility of secession, there would be no absolute legal entitlement to [secession]..." (Supreme Court of Canada, 2010, p. 261) This meant that, even if Quebec voted in favour of secession, the federal government could still deny it to them if the negotiating process failed.

Responses to the secession reference were mixed; both secessionists and federalists claimed victory. Alan Cairns argues that the reference left more questions than answers. (Cairns, A., 1998, p. 26 to 30) Trying to answer one of those questions, the Canadian Government passed The Clarity Act in June, 2000. This bill outlined when and how the Government of Canada would enter into secession negotiations with the provinces. The Clarity Act gave the federal government the right to examine and alter the referendum question for clarity, and determine whether or not the results of the referendum constituted a clear expression of the will to secede. (Government of Canada, 2010, p. 269 to 271) The Act required the government to consider the size of the majority, the percentage of eligible voters that actually voted, and "any other matters or circumstances it considers to be

relevant." (Government of Canada, 2010, p. 271) Lastly, it stipulated that, unless such conditions were met, the federal government had no obligation to enter into negotiations with Quebec. (Government of Canada, 2010, p. 271) 
Indeed, the constitutionality of secession is highly contested in Canada. However, three main principles should be remembered when considering the right to secede. The first is that there is no right to unilaterally secede; there is only a right to the negotiations for secession. Secondly, those negotiations can only be undertaken after a clear majority has expressed an unambiguous desire to secede from the rest of Canada. Lastly, those negotiations must be carried-out in good faith with the hope of coming to a mutually acceptable outcome. Those negotiations, Cairns points out, must acknowledge the fundamental difference between Canada with Quebec, and Canada without Quebec, and seek to come to a resolution that benefits the two new states that will be created if Quebec were to secede. (Cairns, A., 1998, p. 30) The Supreme Court's decision and the subsequent legislative responses exemplify the seriousness of secession and emphasise the care and consideration that must be undertaken to ensure its effectiveness.

\section{The Logistics of Secession: Important Considerations}

There are many issues to consider during the negotiation process. Virtually every aspect of government, economics, international relations, and society must be accounted for. The scope of this paper is too narrow to consider all of these options. However, three examples have been selected to demonstrate the difficult negotiations that this process will entail. First, Quebec's position in international treaties and organizations such as NAFTA. Second, considerations must be made for those people living in Quebec who do not wish to secede. Third, Quebec's economic situation must be analysed with relation to currency, and the loss of fiscal equalization payments.

Adam Brebner discusses the implications that Quebec's secession would have on NAFTA. He argues that the prevailing belief that Quebec would be able to succeed to NAFTA after secession may be misinformed; Quebec's entry into NAFTA is not automatic. He argues that, because the secession of Quebec would severely alter the economic landscape of North America, negotiations regarding subsidies, investment, labour, and the environment would need to occur before Quebec joined NAFTA. Additionally, the NAFTA agreement specifically indicates that it is between the United States, Canada, and Mexico, thus preventing the succession of any other party, such as Quebec. (Brebner, A., 1997, p. 291 to 300) Lastly, Brebner points to Article 34(2)(b) of the Succession Convention which 
states that succession is not possible if it "would be incompatible with the object and purpose of the treaty or radically change the conditions of its operation." (Secession Convention quoted in Brebner, 1997, p.301) Arguably, the secession of Quebec from Canada would radically change the economic and political system within North America. However, it is important to note that Canada and Quebec would need to negotiate an even more open trade policy than NAFTA could provide in order to prevent "the ceaseless traffic along the 401 being halted by customs barriers..." (Secession Convention quoted in Brebner, 1997, p.306) Although this example specifically addresses Quebec's future in NAFTA, the same considerations must be made for other organizations and agreements such as NATO, NORAD, the UN, and others. In this way, Quebec's future on the world stage, both politically and economically, is at state with secession.

Another major consideration to be made, particularly in the case of Quebec, is how to incorporate those individuals who do not wish to leave the federation. One such group is Quebec's First Nations communities. J. Edward Chamberlin argues that the Meech Lake Accord failed because it neglected the impact that such a piece of legislation would have on the Aboriginal Peoples of Canada. For Chamberlin, the recognition of Quebec as a "distinct society" was a form of constitutional discrimination, especially against Aboriginal Canadians, because it failed to provide an adequate depiction of the diversity of Canada. His main argument is that any special recognition or secession of Quebec could diminish Aboriginal sovereignty and pose a threat to their self-government. (Chamberlin, J. E., 1988, p. 11 to 14) Chamberlin argues that any arrangement must promote the, "full and active participation of aboriginal people," otherwise, it could lead to a, "profoundly flawed view of our country, and of the million or so of our fellow Canadians who have an inheritance of aboriginal rights." (Chamberlin, J. E., 1988, p. 19) Simply put, Quebec's secession would require extensive participation on the part of the First Nations community in order to ensure their adequate representation in the newly created states (i.e., Quebec, and Canada without Quebec).

Additionally, other areas of Quebec have expressed wishes to remain within the Canadian Federation. As a result, Jonathan Kay of the National Post has argued that, if Quebec were to secede from Canada, the federal government should partition those parts of Quebec that do not wish to secede: the northern Cree regions, the Eastern Townships, and 
Montreal. (Kay, J., 2014) His argument rests on two premises. First, "if Canada is divisible, so is Quebec." (Kay, J., 2014) Second, "partition wouldn't be about Canada making any sort of land grab [... it] would be about fulfilling our historical and constitutional obligations to Canadians [...] who have grown up in this country expecting their government to respect basic rights." (Kay, J., 2014) Kay argues that there are several million Quebecers who do not want to leave Canada, for various reasons - political, economic, cultural - and that those people should be allowed to remain in Canada, especially when they are as heavily concentrated as in Montreal. (Kay, J., 2014) Although Kay was writing an editorial, and perhaps took a more satirical approach to solving a problem, he nevertheless highlights an important topic of negotiation in the event of Quebec's secession. Simply put, any secession negotiation must acknowledge the fact that many Quebecers do not want to leave Canada and must, therefore, include some remedy to that situation. Certainly, any recommendation to further partition Quebec would be met with great opposition and could lead to the collapse of the negotiation process.

Finally, the economic relationship between Canada and Quebec would have to be negotiated. Daniel Beland and Andre Lecours note that secession would mean the loss of fiscal equalization payments for Quebec. These payments account for roughly 7\% of Quebec's budget. They argue that, if Quebec were to secede, it could lead to fiscal isolation, the loss of transfers (i.e., equalization payments and others), as well as removal from NAFTA. (Beland D. and A. Lecours, 2014, p. 342 to 345) Certainly, these consequences would be devastating for the Quebec economy. In order to combat this economic downturn, Parti Quebecois (PQ) Leader Pauline Marois argued that "a sovereign Quebec would use the Canadian dollar, create a Quebec passport and have free flow of people, goods and services with no borders." (Seguin R. and L. Parreaux, 2014) Marois also believes that "[Quebec] may wish to get a seat at the Bank of Canada, but we would accept the Canadian monetary policies." (Pauline Marois quoted in Seguin and Parreaux ) Although sovereign Quebec would be able to use any currency it chose, its influence on policy would depend solely on the federal government allowing such influence; something the government will not be willing to part with easily. (Pauline Marois quoted in Seguin and Parreaux ) In short, fiscal policy and Quebec's economic future will also need to be discussed should Quebec secede. 